\title{
Quality Assurance in Higher Education According to AUN-QA: A Case Study of Private Universities
}

\author{
Submitted $15 / 01 / 20,1^{\text {st }}$ revision $21 / 02 / 20,2^{\text {nd }}$ revision $28 / 03 / 20$, accepted $30 / 04 / 20$
}

\author{
Vo Van Tuan ${ }^{1}$
}

\begin{abstract}
:
Purpose: This study was conducted to assess the training quality assurance status of private universities in Ho Chi Minh City, Vietnam, according to AUN-QA. Based on that, we propose quality assurance solutions for private universities in Ho Chi Minh City.

Design/Methodology/Approach: To assess the training quality assurance status of private universities in Ho Chi Minh City according to AUN-QA, the study conducted the survey on 449 objects of which 381 participated in the survey by questionnaire and 68 participated in an in-depth interview as managers, teachers of 6 private universities in Ho Chi Minh City. The survey was conducted through a questionnaire designed on a Likert scale with 4 levels. The difference in assessing the training quality assurance status of private universities under AUN$Q A$ between two groups of managers and teachers is made through the t-test. Based on assessing the status, we propose solutions to enhance the training quality of private universities in Ho Chi Minh City, according to AUN-QA. To ensure that the solutions are truly effective, we conduct an experimental study before and after the implementation of the proposed solution. To assess the difference before and after applying the solution, we continue to use the t-test. In addition, to ensure that robustness results are obtained, Bayesian t-test analysis continues to be used.

Findings: The evaluation results showed that 12 training quality assurance standards were evaluated. T-test results showed that there was a difference in the evaluation between the group of teachers and the group of managers. There was no difference in the evaluation between 2 groups. Besides, the t-test and Bayesian t-test results also showed that the proposed solutions were effective in practice.

Practical implications: Based on the empirical results, the author proposes solutions to enhance the training quality of private universities in Vietnam, according to AUN-QA.

Originality/Value: Different from previous studies approaching the qualitative method, in this study the author uses quantitative analysis to assess the training quality assurance status of private universities in Ho Chi Minh City, according to AUN-QA. Besides, the proposed solutions were experimented to see the effect before and after application.
\end{abstract}

Keywords: t-test, Bayesian t-test, Quality assurance, higher education.

JEL Codes: I21, I23, M10.

Paper Type: Research case study.

\footnotetext{
${ }^{1}$ Van Lang University, Vietnam, E-mail: vovantuan@vanlanguni.edu.vn
} 


\section{Introduction}

The quality of higher education is also a major concern of the entire community of management organizations and of scientists around the world. Education is particularly important for the growth of a rising nation. Growth in current countries depends primarily on human capital-educational goods (Żelazny and Pietrucha, 2017). Higher education plays a significant role in the development of high-quality human capital to meet the needs of regional transformation. In addition, in the current sense of globalization of human resources and international integration of education, the quality of higher education meets not only national standards but also regional standards (Guziejewska and Majdzińska, 2018).

Over nearly 30 years of innovation, the Vietnamese higher education system has grown strongly in size, variety in types of schools, and forms of training. Higher education has made initial steps to adjust the system structure, improve the curriculum and training process towards modernization. This has contributed significantly to the provision of high-quality human resources for the cause of socio-economic development and international integration. However, besides the achievements, Vietnam's higher education has still many limitations. The main disadvantage of Vietnam's higher education is that the standard of training does not meet the socioeconomic development criteria. If there is no drastic and successful solution, the country will lose its competitive edge in terms of standard and human capital (Central Committee of the Communist Party of Vietnam, 2014).

In the current system of higher education in Vietnam, private universities play an important role, contributing to satisfying the learning needs of society and making a significant contribution to training human resources for the country. Besides the achievements, in private universities still exist some weaknesses in the management of training activities. In general, the quality of training of private universities is still lower than that of public universities. Candidates enrolled in private universities tend to decrease. Besides, some schools have a training scale that exceeds their training capacity. A significant number of graduates have not yet met their professional requirements. Scientific research activities in many schools have not been taken seriously and have not been linked to the work of training. The above weaknesses and shortcomings of private universities have many causes. One of the fundamental reasons is that the training quality assurance in the private universities has not been given adequate attention, has not been proposed, and implemented with scientific and appropriate solutions for the training quality assurance.

This study was conducted to assess the training quality assurance status of private universities in Ho Chi Minh City, Vietnam, according to AUN-QA. Different from previous studies approaching the qualitative method, in this study, the author uses quantitative analysis to assess the training quality assurance status of private universities, according to AUN-QA. Besides, the proposed solutions in this study were experimented to see the effect before and after application. 
The remainder of the article is structured as follows. Section 2 introduces the theoretical background of ensuring the quality of training at private universities. The material and methods are overviewed in Section 3. Empirical results and discussions are provided in Section 4. Section 5 proposes solutions to ensure the training quality of private universities in Ho Chi Minh City, Vietnam.

\section{The Theoretical Background of Ensuring the Quality of Training at Private Universities}

\subsection{The Quality Assurance Training Concept}

Woodhouse (1999) argues that training quality assurance is the systems, policies, procedures, processes, actions, and attitudes identified, developed, and implemented by the competent authority or higher education institutions to achieve, maintain, monitor, and consolidate quality.

UNESCO-IIEP (2006) states that training quality assurance refers to a process of continuously evaluating the quality of a higher education system, educational institutions, and training programs (including evaluation, supervision, assurance, maintenance, and enhancement).

Wilger (1999) suggested that training quality assurance is a complex process through which universities ensure that the quality of educational processes is maintained according to the set standards. Through training quality assurance activities, the university can satisfy itself, students, and other subjects outside the university.

\subsection{The Content of Training Quality Assurance at Private Universities According to $\mathrm{AUN}-\mathrm{QA}$}

In 2005, AUN-QA established standards/evaluation criteria for the quality assurance system (AUN, 2016). The requirements were developed by AUN-QA in accordance with the requirements set by the European Quality Assurance Association (ENQA). It consists of 12 standards and is concretized into 42 criteria, namely:

- Standard 1: Regarding policies, including 3 criteria with the following contents: the school has clear policies, have a clear official strategy on internal quality assurance, the role of stakeholders is clearly described.

- Standard 2: Regarding supervision, including 4 criteria with the following contents: learners' progress, system to track the progress of learners, systematic feedback from the labor market, systematic feedback from former students.

- Standard 3: Regarding periodically reviewing core activities (teaching, researching, and serving the community), including 3 criteria with the following contents: periodically review of teaching/learning activities episode, periodically 
reviewing research activities, periodically reviewing contributions to society and the community.

- Standard 4: Regarding the quality of learning activities, including 4 criteria with the following contents: criteria for the examination and evaluation, examination and evaluation processes, provisions for quality assurance of the examination and evaluation, complaint procedures.

- Standard 5: Regarding quality assurance of officials and employees, including 3 criteria with the contents: the process of appointing officials and employees, staff cadre evaluation system, officials and employees training activities.

- Standard 6: Regarding quality assurance of learning resources, including 3 criteria with the following contents: testing of computer systems, check library system, testing laboratory systems.

- Standard 7: Regarding quality assurance of student support services, including 5 criteria with the following contents: providing information for learners, counseling for learners, policy regime for learners, dormitories for learners, yard, gym.

- Standard 8: Regarding self-assessment, including 5 criteria with the following contents: self-assessment of the internal quality assurance system, self-evaluation of teaching and learning activities, self-assessment of scientific research activities, selfassessment of contribution to society and community, self-assessment of the school.

- Standard 9: Regarding internal evaluation, including 4 criteria with the following contents: internal evaluation of teaching/learning activities, internal evaluation of research activities, internal evaluation to contribute to society and community, internal evaluation of the school.

- Standard 10: Regarding information systems, including 3 criteria with the following contents: general management information system, management information system for teaching and learning, management information system on research activities.

- Standard 11: Information disclosure, including 3 criteria with the following contents: information disclosure about the school, publish information about training programs and qualifications, publish information about research activities.

- Standard 12: Regarding quality manual, including 2 criteria with the following contents: quality assurance manual, handbook is disseminated to teachers and students. 
In this study, the author assesses the training quality assurance status of private universities in Ho Chi Minh City, Vietnam, based on 12 criteria developed by AUNQA.

\section{Material and Methods}

In this study, the author conducts an assessment of the training quality assurance status of private universities in Ho Chi Minh City, according to AUN-QA. Based on assessing the status, the author proposes solutions to enhance the training quality of private universities in Ho Chi Minh City, according to AUN-QA. To ensure that the solutions are truly effective, the author conducts an experimental study of the improvement before and after the implementation of the proposed solution.

\subsection{Assess the Training Quality Assurance Status of Private Universities in Ho Chi Minh City Ho Chi Minh According to AUN-QA}

To assess the training quality assurance status of private universities in Ho Chi Minh City, according to AUN-QA, the study conducted the survey on 449 objects of which 381 participated in the survey by questionnaire; 68 participated in the in-depth interview as managers, teachers of 6 private universities in Ho Chi Minh City, including Van Lang University, Van Hien University, University of EconomicsFinance, Nguyen Tat Thanh University, Hong Bang University, Ho Chi Minh City University of Technology. The survey was conducted through a questionnaire designed on a Likert scale with 4 levels for questions. The scales are assessed through the average score according to the following convention:

Table 1. Evaluation convention table

\begin{tabular}{|c|c|c|c|}
\hline Level & Score & Level of performance & Results \\
\hline 1 & $1 \leq$ Score $<1.75$ & Never & Very poor \\
\hline 2 & $1.75 \leq$ Score $<2.5$ & Rately & Poor \\
\hline 3 & $2.5 \leq$ Score $<3.25$ & Usually & Fair \\
\hline 4 & $3.25 \leq$ Score $\leq 4$ & Always & Good \\
\hline
\end{tabular}

Source: Pimentel (2019).

The difference in assessing the training quality assurance status of private universities under AUN-QA between two groups of managers and teachers is made through the ttest. In this study, the author used the t-test to assess the difference between group means. The t-test assesses whether the means of two groups are statistically different from each other. This analysis is appropriate whenever you want to compare the means of two groups, and especially appropriate as the analysis for the posttest-only twogroup randomized experimental design.

Figure 1 shows the distributions for the treated (red) and control (black) groups in a study. Actually, the figure shows the idealized distribution - the actual distribution would usually be depicted with a histogram or bar graph. The figure indicates where 
the control and treatment group means are located. The question the t-test addresses is whether the means are statistically different.

Figure 1. Idealized distributions for treated and comparison group posttest values

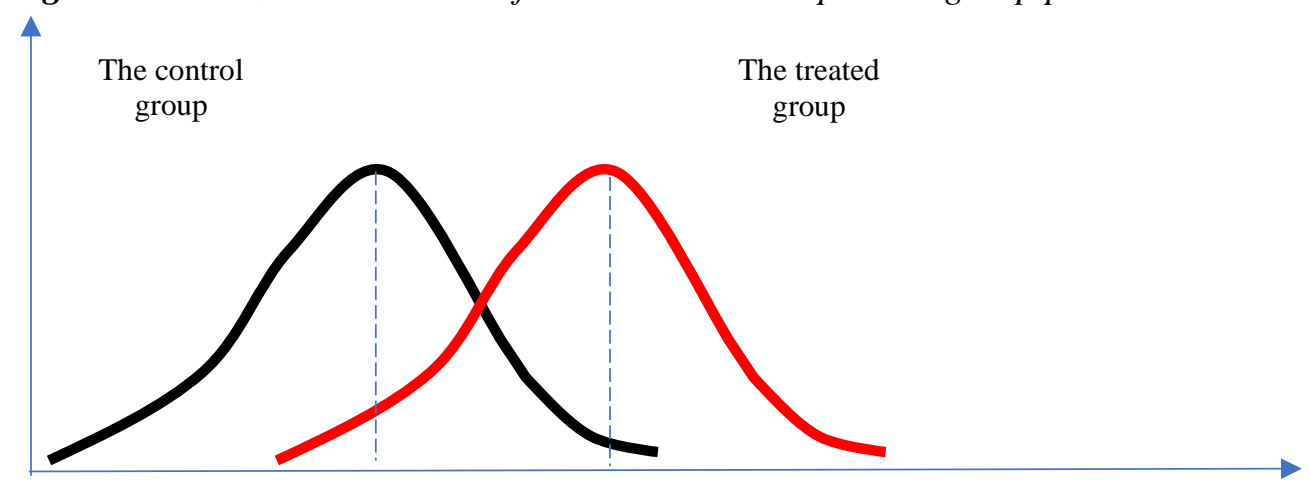

Source: Trochim et al. (2016).

The formula for the t-test is a ratio. The top part of the ratio is just the difference between the two means or averages. The bottom part is a measure of the variability or dispersion of the scores. This formula is essentially another example of the signal-tonoise metaphor in research: the difference between the means is the signal that, in this case, the author thinks our program or treatment introduced into the data; the bottom part of the formula is a measure of variability that is essentially noise that may make it harder to see the group difference. Figure 2 shows the formula for the t-test and how the numerator and denominator are related to the distributions.

Figure 2. The formula for the t-test

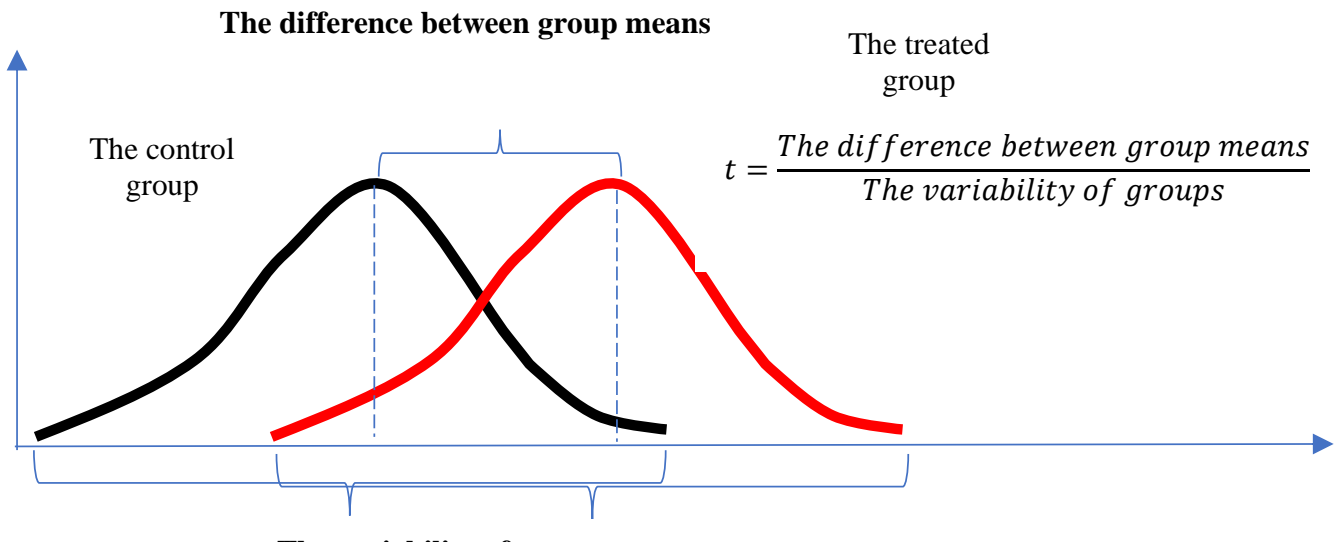

The variability of groups

Source: Trochim et al. (2016).

The $\mathrm{t}$ statistic is: 
$t=\frac{\bar{y}_{T}-\bar{y}_{C}}{\sqrt{\frac{s_{p}^{2}}{n_{p}}}}$

Where:

$s_{p}^{2}=\frac{\left(n_{T}-1\right) s_{T}^{2}+\left(n_{C}-1\right) s_{C}^{2}}{n_{T}+n_{C}-2}$

$n_{p}=\left(n_{T}^{-1}+n_{C}^{-1}\right)^{-1}$

and $\bar{y}_{T}, \bar{y}_{C}, s_{T}^{2}, s_{C}^{2}$ are the sample means and the sample variances for groups, $n_{T}, n_{C}$ are the sample sizes for groups.

The t-test is commonly used for testing $\mathrm{H}_{0}$ : no difference between group means, against the two-sided alternative $\mathrm{H}_{1}$ : there is a difference between group means. $\mathrm{H}_{0}$ is rejected in favor of $\mathrm{H}_{1}$ when the $\mathrm{p}$-value is less than 0.05 . If $\mu_{1}, \mu_{2}$ are the mean values of the treated and control groups, respectively, and common variance $\sigma^{2}$, we will have:

$H_{0}: \mu_{1}=\mu_{2}$ vesus $H_{1}: \mu_{1} \neq \mu_{2}$

\subsection{Evaluate the Effectiveness of Solutions to Enhance Training Quality Assurance for Private Universities According to AUN-QA}

The effectiveness of solutions to enhance training quality assurance for private universities in Ho Chi Minh City, according to AUN-QA was evaluated through experimental research. Specifically:

Experimental research was conducted with a sample of 61 teachers of Van Lang University with seniority in testing subjects mainly for more than 15 years (80.5\%), seniority in teaching work averaged 8.91 years.

Testing to prove the hypothesis: If the training solution is suitable with practical conditions of private universities in Ho Chi Minh City, teachers will understand and apply in practice the evaluation criteria of training quality according to AUN-QA; teaching capacity of the faculty of private universities will improve, from which the quality assurance of private universities will be effective.

To assess the difference before and after applying the solution, the author continues to use t-test. In addition, to ensure that robustness results are obtained, Bayesian t-test analysis continues to be used.

In the general Bayesian formulation of hypothesis testing, one places prior 
probabilities $\pi_{0}$ and $\pi_{1}\left(\pi_{0}+\pi_{1}=1\right)$ on hypotheses $\mathrm{H}_{0}$ and $\mathrm{H}_{1}$, respectively, then updates these values via Bayes theorem to obtain the posterior probabilities.

$P\left(H_{j} \mid\right.$ data $)=\frac{\pi_{j} P\left(\text { data } \mid H_{j}\right)}{\pi_{0} P\left(\text { data } \mid H_{0}\right)+\pi_{1} P\left(\text { data } \mid H_{1}\right)}, j=0,1$

where $P\left(\right.$ data $\left.\mid H_{j}\right)$ denotes the marginal density of the data under hypothesis $\mathrm{j}$. Since the posterior probabilities are sensitive to the priors $\pi_{0}$ and $\pi_{1}$, it is often suggested to use the Bayes factor $(\mathrm{BF})$ instead:

$B F=\frac{P\left(\text { data } \mid H_{0}\right)}{P\left(\text { data } \mid H_{1}\right)}$

Where $\mathrm{BF}>1$, the data provides evidence for $\mathrm{H}_{0}$, and when $\mathrm{BF}<1$, the data provide evidence for $\mathrm{H}_{1}$. Jeffreys (1961) suggests $\mathrm{BF}<0.1$ provides "strong" evidence against $\mathrm{H} 0$ and $\mathrm{BF}<0.01$ provides "decisive" evidence. The posterior probability is simply related to the Bayes factor as:

$P\left(H_{0} \mid\right.$ data $)=\left[1+\frac{\pi_{1}}{\pi_{0}} \frac{1}{B F}\right]^{-1}$

For the hypothesis testing problem in (4), the author needs to specify appropriate prior distributions for $\left(\boldsymbol{\mu}_{1}, \boldsymbol{\mu}_{2}, \boldsymbol{\sigma}^{2}\right)$. Gonen et al. (2005) show that this testing problem can be written in an equivalent form as:

$H_{0}: \delta=\mu_{1}-\mu_{2}=0$ vesus $H_{1}: \delta \neq 0$

Therefore, they advocate a prior for $\boldsymbol{\delta} / \boldsymbol{\sigma}^{2}$, instead of $\boldsymbol{\mu}$, where $\boldsymbol{\mu}=\left(\boldsymbol{\mu}_{1}+\boldsymbol{\mu}_{2}\right) / \mathbf{2}$. After reparameterization from $\left(\boldsymbol{\mu}_{1}, \boldsymbol{\mu}_{2}, \boldsymbol{\sigma}^{\mathbf{2}}\right)$ to $\left(\boldsymbol{\mu}, \boldsymbol{\delta}, \boldsymbol{\sigma}^{2}\right)$, the suggested priors are given by:

$\pi\left(\mu, \sigma^{2}\right) \propto \frac{1}{\sigma^{2}}$ and $\delta / \sigma \mid \mu, \delta, \sigma^{2} \neq 0 \sim N\left(\lambda, \sigma_{a}^{2}\right)$,

where $\lambda$ and $\boldsymbol{\sigma}_{\boldsymbol{a}}^{2}$ are the hyperparameters that need to be pre-specified. Due to lack of prior knowledge in practice, it is natural to set $\lambda=0$ to reflect the uncertain direction of an effect. Thus, the case for which $\lambda=0$ will be of interest to us in what follows. The Bayes factor under the above priors is

$$
B F=\left[\frac{1+\frac{t^{2}}{v}}{1+\frac{t^{2}}{v\left(1+n_{\delta} \sigma_{a}^{2}\right)}}\right]^{-\frac{v+1}{2}}\left(1+n_{\delta} \sigma_{a}^{2}\right)^{-1 / 2}
$$


where $\boldsymbol{v}=\boldsymbol{n}_{1}+\boldsymbol{n}_{2}-\mathbf{2}$. Note that the Bayes factor depends on the data only through the t-statistic and can often be calculated using a pocket calculator.

\section{Results of the Assessment of the Training Quality Assurance Status of Private Universities According to AUN-QA}

\section{* Evaluation of standard 1:}

Table 2. Evaluation results of standard 1

\begin{tabular}{|c|c|c|c|c|c|c|c|c|}
\hline \multirow{2}{*}{ ID } & \multirow[t]{2}{*}{ Content } & \multicolumn{2}{|c|}{ Total } & \multicolumn{2}{|c|}{$\begin{array}{c}\text { Manager } \\
\text { group }\end{array}$} & \multicolumn{2}{|c|}{ Teacher group } & \multirow{2}{*}{ p-value } \\
\hline & & Score & SD & Score & SD & Score & SD & \\
\hline 1 & The school has a clear QA policy & 3.19 & 0.423 & 3.28 & 0.823 & 3.17 & 0.653 & * \\
\hline 2 & $\begin{array}{l}\text { The school has a clear official } \\
\text { strategy on internal QA }\end{array}$ & 3.29 & 0.693 & 2.96 & 0.482 & 3.34 & 0.620 & $*$ \\
\hline 3 & $\begin{array}{l}\text { The roles of stakeholders are clearly } \\
\text { described }\end{array}$ & 2.47 & 0.592 & 2.54 & 0.534 & 2.46 & 0.534 & $*$ \\
\hline & Total & 2.98 & 0.485 & 2.93 & 0.541 & 2.99 & 0.623 & $*$ \\
\hline
\end{tabular}

Note: * corresponds to a p-value greater than 0.05 , Score is the average point value, $S D$ is the standard deviation.

Source: Results from SPSS 25.0 software.

Standard 1 is related to the quality assurance policies, including 3 criteria. The quality assurance policies of private universities in Ho Chi Minh City is rated at a "Fair" rating $(2.5<$ Score $=2.98<3.25)$. Although the evaluation of the subject group of teachers with Score higher than that of the managers' group, t-test results showed that there was no difference between the two groups on this issue ( $\mathrm{p}$-value $>0.05$ ).

\section{* Evaluation of standard 2:}

Standard 2 evaluates supervisory activities according to AUN-QA, interested in the aspect of the subject who carries out the evaluation activities, including students, managers, labor market, and alumni. The evaluation results of standard 2 are presented in Table 3 as follows:

Table 3. Evaluation results of standard 2

\begin{tabular}{|c|c|c|c|c|c|c|c|c|}
\hline \multirow[t]{2}{*}{ ID } & \multirow[t]{2}{*}{ Content } & \multicolumn{2}{|c|}{ Total } & \multicolumn{2}{|c|}{$\begin{array}{l}\text { Manager } \\
\text { group }\end{array}$} & \multicolumn{2}{|c|}{ Teacher group } & \multirow[t]{2}{*}{ p-value } \\
\hline & & Score & SD & Score & SD & Score & SD & \\
\hline 1 & $\begin{array}{l}\text { Quality of training is shown by the } \\
\text { progress of students }\end{array}$ & 3.15 & 0.451 & 2.94 & 0.526 & 3.18 & 0.489 & 0.04 \\
\hline 2 & $\begin{array}{l}\text { There is a system to monitor the } \\
\text { progress of students }\end{array}$ & 3.10 & 0.416 & 3.08 & 0.468 & 3.11 & 0.473 & * \\
\hline 3 & $\begin{array}{l}\text { Collect systematic feedback from the } \\
\text { labor market }\end{array}$ & 3.10 & 0.385 & 3.22 & 0.530 & 3.08 & 0.351 & * \\
\hline 4 & $\begin{array}{l}\begin{array}{l}\text { Collect systematic feedback from } \\
\text { former students }\end{array} \\
\text { forte }\end{array}$ & 2.98 & 0.439 & 3.08 & 0.601 & 2.97 & 0.537 & * \\
\hline
\end{tabular}




\begin{tabular}{|c|c|c|c|c|c|c|c|c|}
\hline & Total & 3.08 & $\mathbf{0 . 4 5 9}$ & $\mathbf{3 . 0 8}$ & $\mathbf{0 . 5 8 2}$ & $\mathbf{3 . 0 9}$ & $\mathbf{0 . 4 7 1}$ & $*$ \\
\hline
\end{tabular}

Note: * corresponds to a p-value greater than 0.05, Score is the average point value, SD is the standard deviation.

Source: Results from SPSS 25.0 software.

Supervision activities of private universities in Ho Chi Minh City achieved "Fair" (2.5 $<$ Score $=3.08<3.25$ ). Although the evaluation of the subject group of teachers with the score higher than that of the managers' group, t-test results showed that there was no difference between the two groups on this issue ( $p>0.05)$. Among the 4 evaluation criteria for supervisory activities according to AUN-QA, the criterion "Quality of training is shown by the progress of students" has the highest score (3.15), corresponding to ranked "Fair". The evaluation results of the two groups of survey subjects in this criterion are different, the group of teachers is more appreciated than the group of managers (the score of teachers $=3.18$; the score of administrators $=2.94$; $\mathrm{p}$-value $=0.04$ ). This difference is understandable because the teacher is the one who directly teaches and monitors the progress of students.

\section{* Evaluation of standard 3:}

Standard 3 is related to periodically reviewing core activities (teaching, researching, and serving the community), including 3 criteria. The evaluation results of standard 3 are presented in Table 4 as follows:

Table 4. Evaluation results of standard 3

\begin{tabular}{|c|c|c|c|c|c|c|c|c|}
\hline \multirow{2}{*}{ ID } & \multirow[t]{2}{*}{ Content } & \multicolumn{2}{|c|}{ Total } & \multicolumn{4}{|c|}{ Manager group $\mid$ Teacher group } & \multirow{2}{*}{ p-value } \\
\hline & & Score & SD & Score & SD & Score & SD & \\
\hline 1 & $\begin{array}{l}\text { Periodically reviewing } \\
\text { teaching/learning activities }\end{array}$ & 3.33 & 340 & 3.22 & 452 & 3.35 & .355 & $*$ \\
\hline 2 & $\begin{array}{l}\text { Periodically reviewing scientific } \\
\text { research activities }\end{array}$ & 3.47 & .535 & 3.34 & 491 & 3.48 & .385 & * \\
\hline 3 & $\begin{array}{l}\text { Periodically reviewing contributions to } \\
\text { society and the community }\end{array}$ & 3.35 & .323 & 3.32 & .514 & 3.36 & .316 & $*$ \\
\hline & Total & 3.38 & 0.349 & 3.29 & 0.467 & 3.40 & 0.353 & * \\
\hline
\end{tabular}

Note: * corresponds to a p-value greater than 0.05, Score is the average point value, $S D$ is the standard deviation.

Source: Results from SPSS 25.0 software.

The periodic review of core activities of private universities in Ho Chi Minh City is rated "Good" (Score $=3.38>3.25$ ). Although the evaluation of the subject group of teachers with the score is higher than that of the managers' group, t-test results showed that there was no difference between the two groups on this issue ( $\mathrm{p}$-value $>0.05$ ).

\section{* Evaluation of standard 4:}

The quality of learning activities of students is one of the criteria to show the quality of training according to AUN-QA. For quality assurance of training, private 
universities need to assess students' learning activities. The status of assessment activities is shown in Table 5. The quality of students' learning activities is assessed at a "Fair" level $(2.5<$ Score $=3.18<3.25)$. The group of teachers has higher evaluation results with the score higher than the group of managers, and the difference is significant ( $p$-value $=0.04<0.05$ ). The reason for this difference is because the teacher is directly involved in the assessment of student learning activities.

Table 5. Evaluation results of standard 4

\begin{tabular}{|c|c|c|c|c|c|c|c|c|}
\hline \multirow{2}{*}{ ID } & \multirow[t]{2}{*}{ Content } & \multicolumn{2}{|c|}{ Total } & \multicolumn{4}{|c|}{\begin{tabular}{|l|l|} 
Manager group & Teacher group \\
\end{tabular}} & \multirow{2}{*}{ p-value } \\
\hline & & Score & SD & Score & SD & Score & SD & \\
\hline 1 & $\begin{array}{l}\text { Establishment of examination and } \\
\text { evaluation criteria }\end{array}$ & 3.25 & 0.642 & 3.02 & 0.456 & 3.29 & 0.434 & 0.04 \\
\hline 2 & $\begin{array}{l}\text { Announcing the examination and } \\
\text { evaluation process }\end{array}$ & 3.19 & 0.356 & 3.02 & 0.398 & 3.22 & 0.466 & 0.04 \\
\hline 3 & $\begin{array}{l}\text { Issue regulations on examination and } \\
\text { evaluation }\end{array}$ & 3.16 & 0.622 & 2.86 & 0.531 & 3.21 & 0.620 & 0.04 \\
\hline 4 & $\begin{array}{l}\text { Publicity of complaints procedure is } \\
\text { clear and wide }\end{array}$ & 3.12 & 0.355 & 3.02 & 0.485 & 3.14 & 0.456 & * \\
\hline & Total & 3.18 & 0.412 & 2.98 & 0.450 & 3.21 & 0.456 & 0.04 \\
\hline
\end{tabular}

Note: * corresponds to a p-value greater than 0.05 , Score is the average point value, SD is the standard deviation.

Source: Results from SPSS 25.0 software.

\section{Evaluation of standard 5:}

The quality assurance of officials and employees is expressed on three criteria: appointment process, evaluation, and training activities. The results are shown in Table 6 as follows:

Table 6. Evaluation results of standard 5

\begin{tabular}{|c|c|c|c|c|c|c|c|c|}
\hline \multirow[t]{2}{*}{ ID } & \multirow[t]{2}{*}{ Content } & \multicolumn{2}{|c|}{ Total } & \multicolumn{2}{|c|}{$\begin{array}{l}\text { Manager } \\
\text { group }\end{array}$} & \multicolumn{2}{|c|}{ Teacher group } & \multirow[t]{2}{*}{ p-value } \\
\hline & & Score & SD & Score & SD & Score & SD & \\
\hline 1 & $\begin{array}{l}\text { Promulgate procedures for appointing } \\
\text { officials }\end{array}$ & 3.16 & 0.341 & 3.08 & 0.246 & 3.17 & 0.424 & $*$ \\
\hline 2 & $\begin{array}{l}\text { Develop criteria to evaluate officials } \\
\text { and employees }\end{array}$ & 3.26 & 0.234 & 3.28 & 0.302 & 3.26 & 0.452 & $*$ \\
\hline 3 & $\begin{array}{l}\text { Deploying training and retraining } \\
\text { activities for officials and employees }\end{array}$ & 3.13 & 0.319 & 3.16 & 0.344 & 3.13 & 0.419 & * \\
\hline & Total & 3.18 & 0.298 & 3.17 & 0.316 & 3.19 & 0.422 & * \\
\hline
\end{tabular}

Note: * corresponds to a p-value greater than 0.05, Score is the average point value, SD is the standard deviation.

Source: Results from SPSS 25.0 software.

The quality assurance status of officials and employees is assessed at a "Fair" level $(2.5<$ Score $=3.18<3.25)$. Although the evaluation of the group of teachers with the score is higher than that of the managers' group, t-test results showed that there was no difference between the two groups on this issue ( $\mathrm{p}$-value $>0.05$ ). 


\section{Evaluation of standard 6:}

Standard 6 is related to the quality assurance of learning resources, including 3 criteria with the following contents: testing of computer systems, testing the library system, testing laboratory systems. The evaluation results of standard 6 are presented in Table 7 as follows:

Table 7. Evaluation results of standard 6

\begin{tabular}{|c|l|c|c|c|c|c|c|c|}
\hline \multirow{2}{*}{ ID } & \multirow{2}{*}{ Content } & \multicolumn{2}{|c|}{ Total } & \multicolumn{2}{c|}{$\begin{array}{c}\text { Manager } \\
\text { group }\end{array}$} & \multicolumn{2}{|c|}{ Teacher group } & \multirow{2}{*}{ p-value } \\
\cline { 3 - 10 } & & Score & SD & Score & SD & Score & SD & \\
\hline 1 & Testing of computer systems & 3.12 & 0.394 & 2.92 & 0.451 & 3.15 & 0.351 & 0.04 \\
\hline 2 & Testing the library system & 3.19 & 0.341 & 2.86 & 0.485 & 3.24 & 0.357 & 0.03 \\
\hline 3 & Testing laboratory systems & 3.17 & 0.374 & 2.88 & 0.416 & 3.21 & 0.578 & 0.03 \\
\hline & Total & $\mathbf{3 . 1 6}$ & $\mathbf{0 . 3 2 6}$ & $\mathbf{2 . 8 9}$ & $\mathbf{0 . 4 6 2}$ & $\mathbf{3 . 2 0}$ & $\mathbf{0 . 3 6 1}$ & $\mathbf{0 . 0 3}$ \\
\hline
\end{tabular}

Note: * corresponds to a p-value greater than 0.05, Score is the average point value, SD is the standard deviation.

Source: Results from SPSS 25.0 software.

The quality assurance of learning resources of private universities in Ho Chi Minh City is rated by the surveyed objects as "Fair" $(2.5<$ Score $=3.16<3.25)$. The group of teachers has a score higher than that of the group of managers, and this difference is significant $(\mathrm{p}$-value $=0.03<0.05)$. Perhaps checking the learning resources is a regular activity that teachers themselves when observing.

\section{Evaluation of standard 7:}

Standard 7 is related to the quality assurance of student support services, including 5 criteria with the following contents: providing information for learners; counseling for learners; policy regime for learners; dormitories for learners; yard, gym. The evaluation results of standard 7 are presented in Table 8 as follows:

Table 8. Evaluation results of standard 7

\begin{tabular}{|c|l|c|c|c|c|c|c|c|}
\hline \multirow{2}{*}{ ID } & \multirow{2}{*}{ Content } & \multicolumn{2}{|c|}{ Total } & \multicolumn{2}{c|}{$\begin{array}{c}\text { Manager } \\
\text { group }\end{array}$} & \multirow{2}{*}{ Teacher group } & \multirow{2}{*}{ p-value } \\
\cline { 3 - 9 } & & Score & SD & Score & SD & Score & SD & \\
\hline 1 & Providing information for learners & 3.18 & 0.349 & 3.18 & 0.341 & 3.18 & 0.363 & $*$ \\
\hline 2 & Counseling for learners & 3.22 & 0.374 & 3.08 & 0.305 & 3.24 & 0.325 & 0,04 \\
\hline 3 & Policy regime for learners & 3.19 & 0.409 & 3.12 & 0.403 & 3.20 & 0.451 & $*$ \\
\hline 4 & Dormitories for learners & 2.75 & 0.351 & 2.88 & 0.395 & 2.66 & 0.460 & 0,04 \\
\hline 5 & Yard, gym & 3.33 & 0.450 & 3.44 & 0.351 & 3.31 & 0.352 & $*$ \\
\hline & & $\mathbf{3 . 2 1}$ & $\mathbf{0 . 4 1 6}$ & $\mathbf{3 . 1 8}$ & $\mathbf{0 . 3 6 3}$ & $\mathbf{3 . 2 2}$ & $\mathbf{0 . 3 4 6}$ & $*$ \\
\hline
\end{tabular}

Note: * corresponds to a p-value greater than 0.05, Score is the average point value, SD is the standard deviation.

Source: Results from SPSS 25.0 software.

The status of ensuring the quality of student support services of private universities in Ho Chi Minh City is rated at a "Fair" level $(2.5<$ Score $=3.21<3.25)$. In particular, 
the criteria "yard, gym" is assessed corresponding to the "good" rating (Score $=3.33$ ). There was no difference between the two target groups for this issue ( $p$-value $>0.05$ ).

\section{* Evaluation of standard 8:}

The self-assessment is one of the quality assurance standards of the universities from the AUN-QA perspective. There are 5 contents of self-assessment include internal QA system, training activities, scientific research activities, community and social contributions, general school activities. The figures are shown in Table 9 as follows:

Table 9. Evaluation results of standard 8

\begin{tabular}{|c|c|c|c|c|c|c|c|c|}
\hline \multirow{2}{*}{ ID } & \multirow[t]{2}{*}{ Content } & \multicolumn{2}{|c|}{ Total } & \multicolumn{2}{|c|}{$\begin{array}{l}\text { Manager } \\
\text { group }\end{array}$} & \multicolumn{2}{|c|}{ Teacher group } & \multirow{2}{*}{$\begin{array}{c}\text { p- } \\
\text { value }\end{array}$} \\
\hline & & Score & SD & Score & SD & Score & SD & \\
\hline 1 & Self-assessment of internal QA system & 3.25 & 0.553 & 3.26 & 0.407 & 3.25 & 0.399 & * \\
\hline 2 & Self-assessment of training activities & 3.21 & 0.481 & 3.30 & 0.442 & 3.20 & 0.341 & * \\
\hline 3 & $\begin{array}{l}\text { Self-assessment of scientific research } \\
\text { activities }\end{array}$ & 3.19 & 0.460 & 3.16 & 0.431 & 3.20 & 0.379 & * \\
\hline 4 & $\begin{array}{l}\text { Self-assessment of community and social } \\
\text { contributions }\end{array}$ & 3.16 & 0.415 & 2.88 & 0.490 & 3.20 & 0.361 & 0.03 \\
\hline 5 & Self-assessment of general school activities & 3.40 & 0.485 & 3.14 & 0.396 & 3.44 & 0.386 & 0.03 \\
\hline & Total & 3.24 & 0.444 & 3.15 & 0.415 & 3.26 & 0.349 & * \\
\hline
\end{tabular}

Note: * corresponds to a p-value greater than 0.05 , Score is the average point value, SD is the standard deviation.

Source: Results from SPSS 25.0 software.

The status of self-assessment activities of private universities in Ho Chi Minh City is rated at a "Fair" rating $(2.5<$ Score $=3.24<3.25)$. There are $2 / 5$ criteria with scores corresponding to the "good" rating. There are $3 / 5$ criteria with scores corresponding to a "Fair" rating. Although the evaluation of the group of teachers with the score is higher than that of the managers' group, t-test results showed that there was no difference between the two groups on this issue ( $\mathrm{p}$-value $>0.05$ ).

\section{Evaluation of standard 9:}

Standard 9 is related to the internal evaluation, including 4 criteria with the following contents: internal evaluation of teaching/learning activities; internal evaluation of research activities; internal evaluation to contribute to society and community; internal evaluation of the school.

Table 10. Evaluation results of standard 9

\begin{tabular}{|c|c|c|c|c|c|c|c|c|}
\hline \multirow[b]{2}{*}{ ID } & \multirow{2}{*}{ Content } & \multicolumn{2}{|c|}{ Total } & \multicolumn{4}{|c|}{ Manager group Teacher group } & \multirow[b]{2}{*}{ p-value } \\
\hline & & Score & SD & Score & SD & Score & SD & \\
\hline 1 & $\begin{array}{lll}\begin{array}{l}\text { Internal } \\
\text { teaching/learning activities }\end{array} & \text { of } \\
\end{array}$ & 3.17 & 0.424 & 3.18 & 0.341 & 3.16 & 0.402 & * \\
\hline 2 & $\begin{array}{l}\begin{array}{l}\text { Internal evaluation of research } \\
\text { activities }\end{array} \\
\end{array}$ & 3.17 & 0.452 & 3.20 & 0.409 & 3.16 & 0.341 & * \\
\hline
\end{tabular}




\begin{tabular}{|c|l|c|c|c|c|c|c|c|}
\hline 3 & $\begin{array}{l}\text { Internal evaluation to contribute to } \\
\text { society and community }\end{array}$ & 3.16 & 0.462 & 3.12 & 0.381 & 3.17 & 0.309 & $*$ \\
\hline 4 & Internal evaluation of the school & 3.28 & 0.469 & 3.14 & 0.356 & 3.31 & 0.430 & $*$ \\
\hline & Total & $\mathbf{3 . 1 9}$ & $\mathbf{0 . 4 6 2}$ & $\mathbf{3 . 1 6}$ & $\mathbf{0 . 3 6 9}$ & $\mathbf{3 . 2 0}$ & $\mathbf{0 . 3 3 0}$ & $*$ \\
\hline
\end{tabular}

Note: * corresponds to a p-value greater than 0.05, Score is the average point value, SD is the standard deviation.

Source: Results from SPSS 25.0 software.

The status of the internal evaluation activities of private universities in Ho Chi Minh City is assessed at the level of "Fair" $(2.5<$ Score $=3.19<3.25)$. There is 1 criteria that has a score corresponding to the "good" rating. There are 4 criteria with scores corresponding to a "Fair" rating. Although the evaluation of the group of teachers with the score is higher than that of the managers' group, t-test results showed that there was no difference between the two groups on this issue ( $p$-value $>0.05$ ).

\section{* Evaluation of standard 10:}

Standard 10 is related to the information systems, including 3 criteria with the following contents: general management information system, management information system for teaching and learning, Management information system on research activities (Table 11).

Table 11. Evaluation results of standard 10

\begin{tabular}{|c|c|c|c|c|c|c|c|c|}
\hline \multirow{2}{*}{ ID } & \multirow{2}{*}{ Content } & \multicolumn{2}{|c|}{ Total } & \multicolumn{2}{|c|}{$\begin{array}{l}\text { Manager } \\
\text { group }\end{array}$} & \multicolumn{2}{|c|}{ Teacher group } & \multirow{2}{*}{ p-value } \\
\hline & & Score & SD & Score & SD & \begin{tabular}{|l|l|} 
Score \\
\end{tabular} & SD & \\
\hline 1 & $\begin{array}{l}\text { General management information } \\
\text { system }\end{array}$ & 3.14 & .402 & 3.12 & .349 & 3.15 & .341 & * \\
\hline 2 & $\begin{array}{l}\text { Management information system for } \\
\text { teaching and learning }\end{array}$ & 3.29 & .451 & 3.06 & .429 & 3.33 & .363 & 0.03 \\
\hline 3 & $\begin{array}{l}\text { Management information system on } \\
\text { research activities }\end{array}$ & 3.19 & .395 & 3.12 & .413 & 3.20 & .340 & * \\
\hline & $\begin{array}{r}\text { Total } \\
\end{array}$ & 3.21 & 0.419 & 3.10 & 0.386 & 3.22 & 0.356 & $*$ \\
\hline
\end{tabular}

Note: * corresponds to a p-value greater than 0.05 , Score is the average point value, SD is the standard deviation.

Source: Results from SPSS 25.0 software.

The status of the information system of private universities in Ho Chi Minh City is assessed at the level of "Fair" $(2.5<$ Score $=3.21<3.25)$. There is 1 criteria with a score corresponding to the "good" rating. There are 2 criteria of the criteria with scores corresponding to the "Fair" rating. Although the evaluation of the group of teachers with the score is higher than that of the managers' group, t-test results showed that there was no difference between the two groups on this issue ( $p$-value $>0.05$ ).

\section{* Evaluation of standard 11:}

Information disclosure is one of the standards for evaluating quality assurance of 
universities, according to AUN-QA. The content of published information is an issue of AUN-QA, including information about schools, training programs and qualifications, and scientific research activities. The actual situation of information disclosure is shown in Table 12. The status of information disclosure activities of private universities in Ho Chi Minh City is assessed at the level of "Fair" $(2.5<$ Score $=3.22<3.25$ ). Although the evaluation of the group of teachers with the score is higher than that of the managers' group, t-test results showed that there was no difference between the two groups on this issue ( $p$-value $>0.05)$.

Table 12. Evaluation results of standard 11

\begin{tabular}{|c|c|c|c|c|c|c|c|c|}
\hline \multirow{2}{*}{ ID } & \multirow{2}{*}{ Content } & \multicolumn{2}{|c|}{ Total } & \multicolumn{2}{|c|}{ Manager group } & \multicolumn{2}{|c|}{ Teacher group } & \multirow{2}{*}{ p-value } \\
\hline & & Score & SD & Score & SD & Score & SD & \\
\hline 1 & $\begin{array}{l}\text { Disclosure of information about the } \\
\text { school }\end{array}$ & 3.12 & 0.314 & 3.12 & 0.362 & 3.12 & 0.402 & $*$ \\
\hline 2 & $\begin{array}{l}\text { Disclose information about the } \\
\text { training program and qualifications }\end{array}$ & 3.33 & 0.351 & 3.14 & 0.395 & 3.36 & 0.362 & 0.04 \\
\hline 3 & $\begin{array}{l}\text { Disclose information on scientific } \\
\text { research activities }\end{array}$ & 3.21 & 0.391 & 3.08 & 0.351 & 3.23 & 0.357 & $*$ \\
\hline & Total & 3.22 & 0.374 & 3.11 & 0.382 & 3.24 & 0.351 & $*$ \\
\hline
\end{tabular}

Note: * corresponds to a p-value greater than 0.05, Score is the average point value, SD is the standard deviation.

Source: Results from SPSS 25.0 software.

\section{Evaluation of standard 12:}

Standard 12 is related to the quality manual, including 2 criteria with the following contents: quality assurance manual; Handbook is disseminated to teachers and students (Table 13).

Table 13. Evaluation results of standard 12

\begin{tabular}{|c|l|c|c|c|c|c|c|c|}
\hline \multirow{2}{*}{ ID } & \multirow{2}{*}{ Content } & \multicolumn{2}{|c|}{ Total } & \multicolumn{2}{c|}{$\begin{array}{c}\text { Manager } \\
\text { group }\end{array}$} & \multicolumn{2}{|c|}{ Teacher group } & \multirow{2}{*}{ p-value } \\
\cline { 3 - 10 } & & Score & SD & Score & SD & Score & SD & \\
\hline 1 & Have quality assurance manual & 3.34 & 0.452 & 3.16 & 0.349 & 3.37 & 0.452 & 0.03 \\
\hline 2 & $\begin{array}{l}\text { Handbook is disseminated } \\
\text { teachers and students }\end{array}$ & 3.16 & 0.406 & 2.92 & 0.391 & 3.20 & 0.361 & 0.03 \\
\hline \multicolumn{2}{|c|}{ Total } & $\mathbf{3 . 2 5}$ & $\mathbf{0 . 4 2 1}$ & $\mathbf{3 . 0 4}$ & $\mathbf{0 . 3 6 8}$ & $\mathbf{3 . 2 8}$ & $\mathbf{0 . 4 0 3}$ & $\mathbf{0 . 0 3}$ \\
\hline
\end{tabular}

Note: $*$ corresponds to a p-value greater than 0.05, Score is the average point value, SD is the standard deviation.

Source: Results from SPSS 25.0 software.

The status of quality manual of private universities in Ho Chi Minh City is assessed at the level of "Good" (Score = 3.25). However, the dissemination of Handbook to teachers and students only reached the level of "Fair" $(2.5<$ Score $=3.16<3.25)$. The difference between the two groups of objects is significant. 


\section{Solutions to Ensure the Training Quality of Private Universities}

\subsection{Proposal of Solutions}

By raising awareness of the quality of training, we are ensuring the quality of training according to AUN-QA for teaching staff and managers. To do this, private universities need to carry out:

$>$ Develop projects and awareness-raising plans for managers at all levels, teachers on training quality and QA according to AUN-QA;

$>$ Organize the implementation of awareness-raising schemes for managers at all levels, teachers on the quality of training and quality assurance according to AUN-QA;

$>$ Directing the implementation of plans and programs to raise awareness for managers at all levels, teachers on QA according to AUN-QA;

$>$ Checking and evaluating the implementation of awareness-raising plans and programs for managers, teachers of training quality and QA, according to AUN-QA.

Develop policies to ensure the quality of training to enhance the participation of stakeholders. To do this, private universities need to implement:

$>$ Develop a system of criteria for evaluating training quality according to AUNQA; Develop policies to ensure training quality according to AUN-QA;

$>$ Revise and finalize the training quality management policy of private universities.

Developing human resources to meet the training quality, according to AUN-QA. To do this, private universities need to implement:

$>$ Build organizational structure, staff in charge of ensuring the quality of training;

$>$ Developing managers and lecturers.

Innovating training methods to meet the requirements of stakeholders. To do this, private universities need to carry out:

$>$ Investigate the needs of stakeholders in QA;

$>$ Promulgate documents directing the innovation of training methods;

$>$ Organize capacity building for teachers and students to adapt to new training methods; Organize communication on innovating training methods in the direction of meeting the requirements of stakeholders. 


\subsection{Experimental Results of Proposed Solutions}

The purpose of testing is to verify the effectiveness of the solution implementation: "Raising awareness of the quality of training, ensuring the quality of training according to AUN-QA for teaching staff and managers." The results of the t-test and Bayes Factor (BF) of awareness of evaluation criteria for training quality according to AUN-QA before and after the test are presented in Table 14 .

Table 14. Awareness of evaluation criteria of training quality according to AUN-QA before and after the test

\begin{tabular}{|c|c|c|c|c|c|c|c|}
\hline \multirow{2}{*}{ ID } & \multirow{2}{*}{ Content } & \multicolumn{2}{|c|}{ Before } & \multicolumn{2}{|c|}{ After } & \multirow{2}{*}{$p$-value } & \multirow{2}{*}{ BF } \\
\hline & & Score & SD & Score & SD & & \\
\hline 1 & Determine the Outcome & 3.14 & 0.23 & 3.47 & 0.27 & ** & 0.04 \\
\hline 2 & Training program & 3.21 & 0.29 & 3.40 & 0.22 & ** & 0.04 \\
\hline 3 & $\begin{array}{l}\text { Structure and content of the training } \\
\text { program }\end{array}$ & 2.97 & 0.31 & 3.17 & 0.34 & $* *$ & 0.03 \\
\hline 4 & Method of teaching & 2.98 & 0.28 & 3.22 & 0.24 & ** & 0.05 \\
\hline 5 & Quality of teaching staff & 3.00 & 0.33 & 3.21 & 0.29 & ** & 0.05 \\
\hline 6 & Quality of support staff & 3.00 & 0.45 & 3.29 & 0.36 & ** & 0.05 \\
\hline 7 & $\begin{array}{l}\text { Examining and evaluating students' } \\
\text { learning activities }\end{array}$ & 2.85 & 0.35 & 3.10 & 0.33 & $* *$ & 0.01 \\
\hline 8 & $\begin{array}{l}\text { Student quality and student support } \\
\text { activities }\end{array}$ & 2.84 & 0.22 & 3.23 & 0.28 & ** & 0.08 \\
\hline 9 & Infrastructure and equipment & 2.79 & 0.24 & 3.19 & 0.21 & ** & 0.04 \\
\hline 10 & Quality improvement solutions & 3.00 & 0.24 & 3.24 & 0.24 & ** & 0.04 \\
\hline 11 & Quality of graduates & 2.88 & 0.31 & 3.10 & 0.33 & ** & 0.08 \\
\hline & Total & 2,86 & $\mathbf{0 . 3 3}$ & 3.27 & 0.29 & $* *$ & 0.03 \\
\hline
\end{tabular}

Note: * corresponds to a p-value greater than $0.05, * *$ corresponds to a p-value less than 0.05 Score is the average point value, SD is the standard deviation.

Source: Results from SPSS 25.0 software.

The statistics in Table 14 show that the average score of awareness of criteria to evaluate training quality of participating teachers has been improved after the experiment (before the experiment: score $=2.86$; after the experiment: score $=3.27$ ). In each evaluation criterion, the average score after the test is higher than before the test. T-test results showed a statistically significant difference at $5 \%$ in each criterion before and after the test. In addition, BF indicators corresponding to each evaluation criteria have values less than 0.1. Thus, according to Jeffreys (1961), this result supports the hypothesis that there are differences in each evaluation criteria before and after the test. Thus, it can be said that the solution "Raising awareness of the quality of training, ensuring the quality of training according to AUN-QA for teaching staff and managers" has brought about practical results.

\section{References:}

AUN. 2016. Guide to AUN-QA asessment at institutional level. Bangkok.

Central Committee of the Communist Party of Vietnam. 2014. Central Resolution No. 32, 
"on continuing to renovate and improve the quality of training and fostering political theory for leading and managing officials", Ha Noi.

Gonen, M., Johnson, O.W., Lu, Y., Westfall, H.P. 2005. The Bayesian two-sample t-test. The American Statistician, 59(3), 252-257.

Guziejewska, B., Majdzińska, A. 2018. The model of municipal education expenditures in Poland. Policy, budget and demography. Equilibrium. Quarterly Journal of Economics and Economic Policy, 13(3), 523-541. doi: 10.24136/eq.2018.026.

Jeffreys, H. 1961. Theory of Probability. Statistics and Computing, 3rd edn. London, Oxford University Press.

Pimentel, L.J. 2019. Some Biases in Likert Scaling Usage and its Correction. International Journal of Sciences: Basic and Applied Research, 45(1), 183-191.

Trochim, M.W., Donnelly, P.J., Arora, K. 2016. Research Methods: The Essential Knowledge Base. Boston, MA, Cengage Learning.

UNESCO-IIEP. 2006. External quality assurance: options for higher education managers. UNESCO-IIEP, Paris.

Wang, M., Liu, G. 2016. A Simple Two-Sample Bayesian t-Test for Hypothesis Testing. The American Statistician, 70(2), 195-201.

Wilger, A. 1997. Quality assurance in higher education: a literature review. Stanford University, Stanford, CA.

Woodhouse, D. 1999. Quality and quality assurance, Quality and Internationalisation in Higher Education. OECD-IMHE, Paris.

Żelazny, R., Pietrucha, J. 2017. Measuring innovation and institution: the creative economy index. Equilibrium. Quarterly Journal of Economics and Economic Policy, 12(1), 43-62. doi: 10.24136/eq.v12i1.3. 